\title{
Study of Root and Stem Rot Pathogen (Rhizoctonia solani) in Different Culture Media, Host Range and Effect of Weather Parameters on Disease Incidence
}

\author{
Tribikram Sahoo ${ }^{1}$, Abhisek Tripathy ${ }^{1 *}$, Shriram Ratan Pradhan ${ }^{2}$ and Anirudha Tarai ${ }^{3}$ \\ ${ }^{1}$ Department of Plant Pathology, O.U.A.T., Bhubaneswar, Odisha, India \\ ${ }^{2}$ Department of Vegetable Science, O.U.A.T., Bhubaneswar, Odisha, India \\ ${ }^{3}$ Department of Agronomy, O.U.A.T., Bhubaneswar, Odisha, India \\ *Corresponding author: abhi.plantpathology@gmail.com (ORCID ID: 0000-0003-3368-4456)
}

Paper No. 857

Received: $10-04-2020$

Revised: 20-07-2020

Accepted: 29-08-2020

\begin{abstract}
Root and stem rot of cowpea caused by Rhizoctonia solani is one of the most important problems for farmers among the coastal regions of Odisha. Keeping this in view, the behavioural study of the pathogen was done by studying its growth pattern in different culture media and host medium. Among five different media, Potato dextrose agar $(90.00 \mathrm{~mm})$ was found to support the maximum radial growth followed by Sabouraud's dextrose agar medium $(87.90 \mathrm{~mm})$, Potato dextrose rose Bengal agar $(82.40 \mathrm{~mm})$, Oat meal agar $(76.60 \mathrm{~mm})$ and Malt extract agar $(70.98 \mathrm{~mm})$. In study of meteorological parameters in relation to disease development the maximum incidence was recorded in October at a maximum temperature of $32.7^{\circ} \mathrm{C}$, minimum temperature $22.9^{\circ} \mathrm{C}$ accompanied by night $\mathrm{RH} 92 \%$ and day $\mathrm{RH} 64 \%$. However, weather parameters under study did not yield any significant effect on disease development. However, the soil factors like sandy loam textured soil and acidic to neutral $\mathrm{P}^{\mathrm{H}}$ contributed towards this soil borne disease. Among host range studies, Rhizoctonia solani isolated from cowpea could infect rice (Oryza sativa), maize (Zea mays), tomato (Solanum lycopersicum), chilli (Capsicum annum), brinjal (Solanum melongena), field pea (Pisum sativum), cucumber (Cucumissataivus), bengalgram (Cicer arietinum), arhar (Cajanus cajan), cotton (Gossypium hirsutum), and groundnut (Arachis hypogea) in addition to its own host.

\section{Highlights}

(0 The most effective supporting medium for growth of the fungus was the Sabouraud's dextrose agar with an incubation period of seven days.

(0) The least infection was found during august when the temperature and $\mathrm{RH}$ were in the range $24-34^{\circ} \mathrm{C}$ and 73-94 per cent respectively.

0 Sandy loam textured soil and acidic to neutral $\mathrm{P}^{\mathrm{H}}$ contributed root and stem rot disease the most.

0 The isolates of rice, maize, tomato, brinjal, chilly, fieldpea, cucumber, Bengal gram, arhar, cotton and groundnut were identical in their pathogenicity as they caused similar infection.
\end{abstract}

Keywords: Host range studies, Potato dextrose agar, Rhizoctonia solani, Root and stem rot

Cowpea diseases induced by different pathogens belonging to various pathogenic groups constitute one of the most constraints to profitable cowpea production in all agro-ecological zones where the crop is cultivated. One among the important diseases which cause considerable loss in the yield is root and stem rot (Rhizoctonia solani), where losses in green fodder and seed yield were estimated to be about 28.8 and 39.7 per cent, respectively (Ram and Gupta, 1988). Rhizoctonia solani (teleomorph: Thanatephorus spp.) is a plant

How to cite this article: Sahoo, T., Tripathy, A., Pradhan, S.R. and Tarai, A. (2020). Different Culture Media, Host Range and Effect of Weather Parameters on Disease Incidence. IJAEB, 13(3): 355-359.

Source of Support: None; Conflict of Interest: None (9) क्ष 
pathogenic fungus with a wide host range and worldwide distribution. $R$. solani frequently exists as thread-like growth on plants or in culture and is considered a soil-borne pathogen. $R$. solani attacks its hosts in their juvenile stages of development. This saprophytic pathogen would survive in the soil and attack the hosts. The pathogen is known to cause serious plant losses by attacking primarily the roots and lower stems of plants. Although it has a wide range of hosts, its main targets are herbaceous plants. So, from this study, we can get a brief idea about how the root and stem rot pathogen can grow in different culture media which in turn will help us to get a conclusion about the pathogen culture. Also we can get to know about how the same pathogen can affect different hosts. Moreover, we can conclude how the pathogen is reacting to different weather conditions.

\section{MATERIALS AND METHODS}

Rhizoctonia solani causes root and stem rot of cowpea. It is a wide spread disease in Odisha causing huge economic loss. Considering the importance of disease, research work was undertaken to study the pathogen and its management through application of bio agents and chemicals both in the laboratory and field during 2014-16 at the AICRP on vegetable crops, Orissa University of Agriculture and Technology, Bhubaneswar and Research facilities of Department of Plant Pathology, OUAT, Bhubaneswar.

In order to find out growth of test fungus, five different culture media viz.,potato dextrose agar, Sabouraud's agar, oat meal agar, malt extract agar and potato dextrose rose bengal agar were selected. The media were prepared with slight modifications where ever necessary.

The $\mathrm{p}^{\mathrm{H}}$ of different media was adjusted to 6.0 before autoclaving. The Petri dishes were inoculated with equal sized mycelial discs made by $5 \mathrm{~mm}$ cork borer from margin of young growing colonies and incubated at $25 \pm 1^{\circ} \mathrm{C}$. Three replications were maintained. The experiment was designed in Complete Randomized Design. Mycelial growth was recorded after seven days of incubation $(\mathrm{mm})$.

In order to study the relationship of meteorological parameters on the natural occurance of Rhizoctonia solani in cowpea, observations were taken from $10 / 08 / 2015$ to $11 / 10 / 2015$ consisting of 2 month meteorological months (2015 Kharif) under field condition at experimental plot of AICRP on vegetable crops, OUAT, Bhubaneswar. The weather parameters like maximum and minimum temperature $\left({ }^{\circ} \mathrm{C}\right)$, maximum and minimum $\mathrm{RH}(\%)$, rainfall $(\mathrm{mm})$ and bright sunshine hours (hr) were co-related with Rhizoctonia disease incidence. The mortality was recorded basing on the intensity of disease appearance on cowpea through visual estimation. Per cent disease incidence (PDI) was calculated by using the formula as mentioned below:

$$
\text { PDI }=\frac{\text { No of plants wilted }}{\text { Total no. of observations }} \times 100
$$

Different plant spp. i.e. Rice (Oryzae sativa), Maize (Oryzae sativa), Tomato (Solanum lycopersicum), Okra (Abelmuschus esculentus), Brinjal (Solanum melongena), Sunflower (Helianthus annus), Coriander (Coriandrum sativum), Chilli (Capsicum annuum), Field pea (Pisum sativum), Raddish (Raphanus sativus), Cucumber (Cucumis sataivus), Bengal gram (Cicer arietinum), Arhar (Cajanus cajan), Cotton (Gossypium hirsutum), and Groundnut (Archis hypogeae) with suspected fungal infection ( root and stem rot) were collected and examined under microscope. The fungal pathogen $R$. solani was brought into pure culture on PDA medium and pathogen was established. Above plant spp. were grown in poly pots and the pathogenic fungal isolates from each plant including cowpea were cross inoculated with each other. The reaction was recorded after seven days of inoculation. Different host plant seeds used in this experiment are enlisted in table 1.

Table 1: List of different seeds used for host range study

\begin{tabular}{|c|c|c|c|}
\hline $\begin{array}{l}\text { Sl. } \\
\text { No. }\end{array}$ & $\begin{array}{l}\text { Common } \\
\text { name }\end{array}$ & Scientific name & Family \\
\hline 1 & Rice & Oryza sativa & Poaceae \\
\hline 2 & Maize & Zea mays & Poaceae \\
\hline 3 & Tomato & $\begin{array}{l}\text { Solanum } \\
\text { lycopersicum }\end{array}$ & Solanaceae \\
\hline 4 & Okra & $\begin{array}{l}\text { Abelmoschus } \\
\text { esculentus }\end{array}$ & Malvaceae \\
\hline 5 & Brinjal & Solanum melongena & Solanaceae \\
\hline 6 & Sunflower & Helianthus annus & Asteraceae \\
\hline 7 & Coriander & Coriandrum sativum & Apiaceae \\
\hline 8 & Chilli & Capsicum annuum & Solanaceae \\
\hline 9 & Field pea & Pisum sativum & Leguminaceae \\
\hline
\end{tabular}




\begin{tabular}{llll}
10 & Raddish & Raphanus satious & Brassicaceae \\
11 & Cucumber & Cucumis satious & Cucurbitaceae \\
12 & Bengal gram & Cicerarietinum & Leguminaceae \\
13 & Arhar & Cajanus cajan & Fabaceae \\
14 & Cotton & Gossypium hirsutum & Malvaceae \\
15 & Groundnut & Arachis hypogeae & Fabaceae \\
\hline
\end{tabular}

Statistical analysis was carried out by following the standard procedures (Panse and Sukhatme 1967). Data in percentage were transformed to angular values before analysis.

\section{RESULTS AND DISCUSSION}

\section{Growth of Rhizoctonia solani in different solid media}

In order to find out a suitable medium for Rhizoctonia solani, five different solid media were tried. Observations on radial growth of the mycelium were recorded after seven days of inoculation. The data obtained are presented in Table 2.

Table 2: Growth of Rhizoctonia solani in different solid media

\begin{tabular}{lll}
\hline $\begin{array}{l}\text { Sl. } \\
\text { No. }\end{array}$ & Name of solid medium & $\begin{array}{l}\text { Radial growth of } \\
\text { colony }(\mathrm{mm})\end{array}$ \\
\hline 1 & Oat meal agar & $76.60^{*}$ \\
2 & Malt extract agar & 70.98 \\
3 & Potato dextrose rose bengal agar & 82.40 \\
4 & Sabouraud's dextrose agar & 87.90 \\
5 & Potato dextrose agar & 90.00 \\
\hline & $\mathrm{SE}(\mathrm{m}) \pm$ & 1.73 \\
\hline & $\mathrm{CD}(0.05)$ & 5.14 \\
\hline
\end{tabular}

The growth of the pathogen Rhizoctonia solani was significantly different in culture media. In the media under study, the growth increased with an increase in incubation period. Potato dextrose agar gave maximum growth of the fungus $(90.00 \mathrm{~mm})$. The most effective supporting medium for growth of the fungus was the Sabouraud's dextrose agar which showed $87.90 \mathrm{~mm}$ diameter mycelial growth of the pathogen after an incubation period of seven days followed by Potato dextrose rose bengal agar (82.40 $\mathrm{mm})$. The minimum growth obtained in Malt extract agar $(70.98 \mathrm{~mm})$. The result showed that, the rate of growth in solid media was significantly different from each other.

In order to obtain adequate knowledge about the pathogen concerning growth characteristics, it was grown on a variety at solid media. The best one for Rhizoctonia solani was potato dextrose agar medium. The most effective supporting medium for the growth of Rhizoctonia solani was Sabouraud's dextrose agar medium. However, Ranganathan et al. (1973) reported that oat meal agar is suitable medium for growth of $R$. solani which is contradiction to the present finding.

\section{Environmental factors affecting growth and disease development by Rhizoctonia solani}

Observations on the incidence of Rhizoctonia solani of cowpea was recorded at weekly intervals as per procedures described earlier. The data of meteorological parameters and disease intensity are presented in Table 3.

It may be seen from the table 3 that, the disease appeared more or less throughout the season in cowpea crop. The least infection was found during august when the temperature and $\mathrm{RH}$ were in the range $24-34{ }^{\circ} \mathrm{C}$ and $73-94$ per cent respectively.

Table 3: Climatic parameters and disease incidence from 13.08.2015 to 14.10.2015

\begin{tabular}{llllllll}
\hline Meterological week & $\begin{array}{l}\text { Max. temp. } \\
\left({ }^{\circ} \mathbf{C}\right)\end{array}$ & $\begin{array}{l}\text { Min. Temp. } \\
\left({ }^{\circ} \mathbf{C}\right)\end{array}$ & Max. RH (\%) & Min. RH (\%) & $\begin{array}{l}\text { Rainfall } \\
(\mathbf{m m})\end{array}$ & BSH (hr) & PDI \\
\hline $13 / 08 / 2015-19 / 08 / 2015$ & 32.1 & 24.9 & 94 & 84 & 36.8 & 3.8 & 1.6 \\
20/08/2015-26/08/2015 & 33.3 & 24.8 & 91 & 73 & 124 & 4.3 & 6.8 \\
$27 / 08 / 2015-02 / 09 / 2015$ & 32 & 25.3 & 94 & 81 & 54.4 & 4.1 & 11.4 \\
$03 / 09 / 2015-09 / 09 / 2015$ & 33.4 & 24.2 & 91 & 69 & 58.5 & 3.4 & 26.8 \\
10/09/2015-16/09/2015 & 32.8 & 24.8 & 92 & 83 & 59.7 & 4.3 & 32 \\
$17 / 09 / 2015-23 / 09 / 2015$ & 32.3 & 25.5 & 94 & 78 & 23.9 & 4.4 & 38.6 \\
$24 / 09 / 2015-30 / 09 / 2015$ & 33.7 & 25.5 & 89 & 67 & 9.4 & 5.7 & 42.2 \\
$01 / 10 / 2015-07 / 10 / 2015$ & 33.9 & 24.7 & 92 & 75 & 35.8 & 6.4 & 44.6 \\
$08 / 10 / 2015-14 / 10 / 2015$ & 32.7 & 22.9 & 92 & 64 & 36.4 & 5.8 & 51 \\
\hline
\end{tabular}


The incidence of Rhizoctonia soalni of cowpea was recorded at weekly interval in the month of August when the temperature and relative humidity were in the range $24-34{ }^{\circ} \mathrm{C}$ and $73-94$ per cent respectively. The maximum disease incidence was found in the month of October when temperature and relative humidity were in the range 22.9 to $32.7^{\circ} \mathrm{C}$ and 64 to 92 per cent respectively. It supports the findings of Parmeter (1970), Harikrishna and Yang (2004) and Goswami et al. (2011). The reports of Parmeter (1970), Homma et al. (1983), Sihna and Ghufran (1988) and Goswami et al. (2011) regarding temperature requirement by $R$. solani is in agreement with the present observation.

Table 4: Co-relation matrix of climatic parameters on disease incidence (Kharif, 2015)

\begin{tabular}{llllllll}
\hline & $\mathbf{X}_{1}$ & $\mathrm{X}_{2}$ & $\mathrm{X}_{3}$ & $\mathrm{X}_{4}$ & $\mathrm{X}_{5}$ & $\mathrm{X}_{6}$ & $\mathrm{Y}$ \\
\hline $\mathrm{X}_{1}$ & 1.000 & & & & & & \\
$\mathrm{X}_{2}$ & -0.090 & 1.000 & & & & & \\
$\mathrm{X}_{3}$ & -0.836 & 0.107 & 1.000 & & & & \\
$\mathrm{X}_{4}$ & -0.576 & 0.536 & 0.699 & 1.000 & & & \\
$\mathrm{X}_{5}$ & 0.062 & -0.116 & -0.066 & 0.096 & 1.000 & & \\
$X_{6}$ & 0.516 & -0.211 & -0.353 & -0.463 & -0.401 & 1.000 & \\
$Y$ & 0.436 & -0.330 & -0.353 & -0.573 & -0.570 & 0.730 & 1.000 \\
\hline
\end{tabular}

The Prediction Equation,

$$
\begin{gathered}
\mathrm{Y}=-151.266+6.372 \mathrm{x}_{1}-4.308 \mathrm{x}_{2}+1.093 \mathrm{x}_{3}- \\
0.512 \mathrm{x}_{4}-0.248 \mathrm{x}_{5}+5.583 \mathrm{x}_{6}
\end{gathered}
$$

Co-efficient of determination $\mathrm{R}^{2}=-1.80$

Where, $X_{1}=$ Maximum Temperature

$$
\begin{aligned}
& X_{2}=\text { Minimum Temperature } \\
& X_{3}=\text { Maximum RH } \\
& X_{4}=\text { Minimum } R H \\
& X_{5}=\text { Rainfall } \\
& X_{6}=\text { Bright sunshine Hours } \\
& Y=\text { Percent disease incidence }
\end{aligned}
$$

It is revealed from the correlation study that, all the weather factors (Maximum Temperature, Minimum Temperature, Maximum RH, Minimum RH, Rainfall and Bright sunshine hours) did not yield any result towards disease development. The maximum disease infection was found in the month of October at maximum temperature $32.7{ }^{\circ} \mathrm{C}$ and minimum temperature $22.9{ }^{\circ} \mathrm{C}$ with maximum $\mathrm{RH} 92 \%$ and minimum $\mathrm{RH} 64 \%$ respectively. Therefore the soil factor was responsible for disease development. Sandy loam textured soil and acidic to neutral $\mathrm{P}^{\mathrm{H}}$ contributed root and stem rot disease as high as $51.00 \%$ in second week of October 2015.

\section{Host range}

The fungal pathogen isolated into pure culture from different hosts as described earlier were cross inoculated and the reaction of each host species after seven days of inoculation have been presented in Table 5. It might be seen (Table 5) that, $R$. solani isolate from cowpea could infect rice (Oryza sativa), maize (Zea mays), tomato (Solanum lycopersicum), chilli (Capsicum annuum), brinjal (Solanum melongena), fieldpea (Pisum sativum), cucumber (Cucumis sataivus), bengalgram (Cicer arietinum), arhar (Cajanus cajan), cotton (Gossypium hirsutum), and groundnut (Arachis hypogeae) in addition to its own host. Similarly the isolate of rice and maize could infect cowpea in addition to their own host. The isolate of tomato (Solanum lycopersicum), brinjal (Solanum melongena) and chilly(Capsicum annuum) could infect each other along with cowpea (Vigna unguiculata). The isolate of okra (Abelmuschus esculentus) and fieldpea (Pisum sativum) could infect each other. Sunflower (Helianthus annus) and groundnut (Archis hypogeae) isolates, cucumber (Cucumi ssataivus), Bengal gram (Cicer arietinum) and arhar (Cajanus cajan) could infect each other in addition to cotton. However, radish (Raphanus sativus) and coriander (Coriandrum sativum) confined to their own hosts only.

It was evident from foregoing observation that the isolates of rice, maize, tomato, brinjal, chilly, fieldpea, cucumber, Bengal gram, arhar, cotton and groundnut were identical in their pathogenicity as they caused similar infection. The symptoms subsequent upon infection by these isolates were similar comprising of formation of reddish-brown lesions just at the soil line i.e. collar region of plant. The lesion increased in size both upward to the stem and downward to the roots with the advancement of the disease, the plants started dying in a few days.

Rhizoctonia solani was more contrast and variable soil inhibiting organism. It has the wider host range such as cereals, cottons, sugarbeet, potato, beans, peas, field crops, horticultural crops, flowers, grasses and forestries. In this studies the isolate of rice, maize, tomato, brinjal, chilly, pea, cucumber, 
Table 5: Reaction of different host species to Rhizoctonia solani occur after 7 days of inoculation

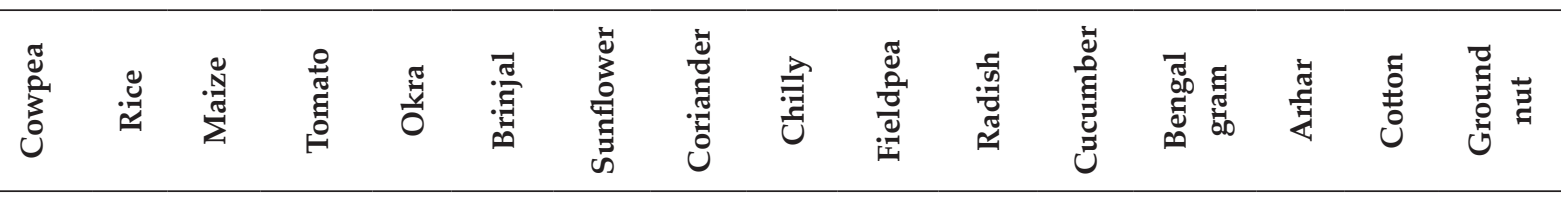

\begin{tabular}{|c|c|c|c|c|c|c|c|c|c|c|c|c|c|c|c|c|}
\hline Cowpea & + & + & + & - & - & - & - & - & - & + & - & + & - & + & + & + \\
\hline Rice & + & + & + & - & - & - & - & - & - & - & - & - & - & - & - & - \\
\hline Maize & + & + & + & - & - & - & - & - & - & - & - & - & - & - & - & - \\
\hline Tomato & + & - & - & + & - & + & - & - & + & - & - & - & - & - & - & - \\
\hline Okra & - & - & - & - & + & - & - & - & - & + & - & - & - & - & - & - \\
\hline Brinjal & + & - & - & + & - & + & - & - & + & - & - & - & - & - & - & - \\
\hline Sunflower & - & - & - & - & - & - & + & - & - & - & - & - & + & - & - & - \\
\hline Coriander & - & - & - & - & - & - & - & + & - & - & - & - & - & - & - & - \\
\hline Chilly & + & - & - & + & - & + & - & - & + & - & - & - & - & - & - & - \\
\hline Fieldpea & + & - & - & + & + & - & - & - & - & + & - & - & + & + & - & - \\
\hline Raddish & - & - & - & + & - & + & - & - & - & - & + & - & - & - & - & - \\
\hline Cucumber & + & - & - & + & - & + & - & - & - & - & - & + & - & - & - & - \\
\hline $\begin{array}{l}\text { Bengel } \\
\text { gram }\end{array}$ & + & - & - & - & - & - & - & - & - & + & - & - & + & + & + & + \\
\hline Arhar & + & - & - & - & - & - & - & - & - & - & - & - & + & + & + & - \\
\hline Cotton & + & - & - & - & + & - & - & - & - & - & - & - & + & + & + & + \\
\hline
\end{tabular}

bengal gram, cotton and groundnut found identical in their pathogenicity and caused similar infection. These expressed the symptoms like pre and postemergence damping off formation of reddish-brown lesions just above the soil line i.e. collar region of plant. The lesion increased in size both upward and downward directions on the plant. At severe infection, the plant started dying and collapse within a few days. It has been ascertained by earlier workers viz. Panwar et al. (2012) on studying the host range of $R$. solani as chickpea, moth bean and mung bean in addition to cowpea.

\section{REFERENCES}

Goswami, B.K., Rahaman. M.M., Hoque, A.K.M.A., Bhuyan, K. and Mian, I.H. 2011. Variations in different Isolates of Rhizoctonia solani based on temperature and $\mathrm{pH}$. Bangladesh J. Agril. Res., 36(3): 389-396.

Harikrishnan, R. and Yang, X.B. 2004. Recovery of anastomosis groups of Rhizoctonia solani from different latitudinal positions and influence of temperatures on their growth and survival. Pl. Dis., 88: 817-823.
Homma, Y., Yamashita, Y. and Ishii, M. 1983. A new anastomosis group (AG7) of $R$. solani Kuhn. From Japanese raddish fields. Annul Phyphath. Soc. Japan, 49(2): 184-190.

Panse, V.G. and Sukhatme, P.V. 1978. Statistical Methods for Agricultural Workers, ICAR Publication, New Delhi, pp. 325.

Panwar, P.K. and Gaur, V.K. 2012. Evaluation of antagonists to Rhizoctonia solani causing wet root rot in chickpea. J. Mycology Pl. Path., 42(4) : 485-488.

Panwar, P.K., Gaur, V.K. and Katariya, L. 2012. Host range and pathogenic variation in isolates of Rhizoctonia solani incitant of wet root rot in chickpea. J. Mycology Pl. Path., 42(3): 489-493.

Parmeter, J.R. 1970. Rhizoctonia solani: Biology and Pathology. University of California Press, Berkeley, Los Angeles and London, pp 1-4.

Ram, S. and Gupta, M.P. 1988. Pest Management in Forage crops. Pasture and Forage crops Research - A state of knowledge Report. Punjab Singh (Ed.) Range Management Society of India. IGFRI, Jhansi-284003, India, pp. 261-269.

Sinha, B.B.P. and Ghufran, S.M. 1988. Physiological studies of five isolates of sheath blight of rice caused by $R$. solani. J. Res.-RAU, 6(2): 61-67. 
